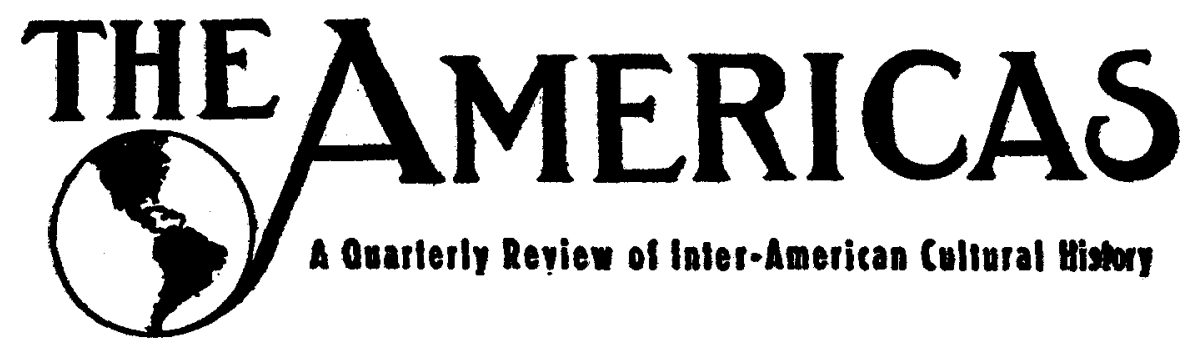

\title{
VOLUME V
}

JULY, 1948, THROUGH APRIL, 1949

\author{
Published Quarterly \\ by the \\ ACADEMY OF AMERICAN Franciscan HISTORY \\ Washington 14, D. C.
}

1949 


\section{ARTICLES}

Juan Bautista Alberdi and His Influence on Immigration

Policy in the Argentine Constitution of 1853

Sam Schulman 3

The First Franciscans of Brazil. .Odulfo van der Vat, O.F.M. 18

The Educational Activities of Fray Alonso de La Vera

Cruz in Sixteenth Century Mexico

Jobn F. Blethen, O.S.A. 31

The Franciscan "Mission" to San Fernando College, Mexico, $1749 \ldots \ldots \ldots \ldots \ldots \ldots \ldots \ldots$. Maynard Geiger, O.F.M. 48

EL MENSAJERO aNd the Election of 1871 in Mexico

Walter $V$. Scholes 61

The Terra Australis-A Franciscan Quest (II) Celsus Kelly, O.F.M. 68

The Indian Policy of Portugal in America, With Special

Reference to the Old State of Maranhão, 1500-1755 Mathias C. Kiemen 131; 439

What Became of Jolliet's Journal? . . . . Francis Borgia Steck 172 The Palmares "Republic" of Pernambuco, Its Final

Destructron, 1697 .................Ernesto Ennes 200

Franciscan History and Fray Juan de Zumárraga

Thomas Plassmann 261

Fray Juan de Zumárraga-His Social Contributions

James A. Magner 264

The Contribution of Bishop Juan de Zumárraga to Mexican

Culture ........................ Lewis Hanke 275

Fray Juan de Zumárraga, Protector of the Indians

Fidel de J. Chauvet 283

Fray Juan de Zumárraga and Indian Policy in New Spain

Carlos E. Castañeda 296

The Books of Don Fray Juan de Zumárraga

Alberto María Carreño

Bishop Marroquín-Zumárraga's Gift to Central America

Lázaro Lamadrid

The French in Sixteenth-Century Brazil . Charles E. Nowell 381

Origin of the Franciscan Order in Colombia

Gregorio Arcila Robledo 394

Father Marquette's Place in American History

Francis Borgia Steck 411 


\section{SURVEY}

Writings on United States Catholic History: 1948

A Selective Bibliography .... Thomas $F$. O'Connor 462

IN MEMORIAM

The Most Rev. Paschal Robinson, O.F.M......... 217

Maximin Chardes Piette, O.F.M............... 342

\section{DOCUMENTS}

A Chapter List of the Province of St. Georee of Nicaragua, 1638...... (Ed.) Lázaro Lamadrid, O.F.M. 95

Jacques Arago and the Imperial Family of Brazil (Ed.) David James 221

Ax Unpublished Letter of Don Francisco Marroquín, First Bishop of Guatemala, to the Emperor Charles V (Guatemala, August 17, 1545)

(Ed.) Lázaro Lamadrid 344

Questionnatre of the Spanish Government in 1812 Concerning the Native Culture of the California Mission Imdians .............(Ed.) Mayzard Geiger 474

\section{INTER-AMERICAN NOTES \\ INTER-AMERICAN NOTES $\ldots \ldots \ldots \ldots \ldots \ldots \ldots \ldots$ 104; 226}

Annual Academic Session of the Academy of American

Franciscan History $\ldots \ldots \ldots \ldots \ldots \ldots \ldots \ldots \ldots, 346$

"The Americas Award" Conferred on Dr. Pablo,

Martínez del Río $\ldots \ldots \ldots \ldots \ldots \ldots \ldots \ldots \ldots ., 348$

\section{BOOK REVIEWS}

